\title{
Comparison of the effects of the dietary addition of two lactic acid bacteria on the development and conformation of sea bass larvae, Dicentrarchus labrax, and the influence on associated microbiota
}

\author{
Faouzi Lamari, ${ }^{\mathrm{a}, \mathrm{b}}$, Mathieu Castex ${ }^{\mathrm{c}}$, Thibaut Larcher ${ }^{\mathrm{d}}$, Mireille Ledevin ${ }^{\mathrm{d}}$, David Mazurais ${ }^{\mathrm{a}}$, \\ Amina Bakhrouf ${ }^{\mathrm{b}}$, François-Joël Gatesoupe ${ }^{\mathrm{e}, \text { * }}$
}

\footnotetext{
a Ifremer, UMR 6539 LEMAR, Laboratoire "Adaptation, Reproduction, Nutrition” (ARN), Centre de Brest, BP 70, 29280 Plouzané, France

${ }^{\mathrm{b}}$ Faculty of Pharmacy, Laboratoire "Analyse, Traitement et Valorisation des Polluants de l'Environnement et des Produits", rue Avicenne, Monastir 5000, Tunisia

${ }^{c}$ Lallemand Animal Nutrition, BP 59, 31702 Blagnac, France

¿ INRA, UMR0703 APEX, Oniris, La Chantrerie, BP 40706, 44307 Nantes Cédex 3

e INRA, UR 1067 "Nutrition, Métabolisme, Aquaculture", Ifremer, Centre de Brest, BP 70, 29280 Plouzané, France
}

\author{
*: Corresponding author: François-Joël Gatesoupe, Tel.: + 33298224389 ; fax: + 33298224366. \\ email address : joel.gatesoupe@ifremer.fr \\ email address : lamari.faouzi@gmail.com ; mcastex@lallemand.com ; thibaut.larcher@nantes.inra.fr ; \\ david.mazurais@ifremer.fr
}

\begin{abstract}
:
Probiotics may have many effects on health and development of fish larvae. One of the most promising is related to spinal conformation, though the mode of action is not clearly understood. The present study attempted to investigate the effects of two strains of lactic acid bacteria on associated microbiota, histological development and gene expression. Sea bass larvae were fed since 5 dph (day post hatch) with either a standard control diet (Diet C), or the same diet supplemented with Pediococcus acidilactici MA18/5 M (Diet P), or with an autochthonous strain of Lactobacillus casei (X2; Diet L). The two lactic acid bacteria were incorporated in the diets at the levels of $10^{6}$ and $10^{7} \mathrm{CFU}$ (colony forming units) $\mathrm{g}^{-1}$ in two consecutive experiments, respectively. The experimental treatments maintained the lactic acid bacteria above the detection threshold in the larvae. In the second experiment, the Bray-Curtis indices revealed the dissimilarity between the Bacterial Community Profiles (BCPs) associated with Diet $P$ and those of the two other dietary groups. The two lactic acid bacteria promoted growth, especially by 20-22 dph, but the development seemed affected differently in the two groups. The osteocalcin gene was overexpressed at 20-22 dph in group L, suggesting a difference in the early bone development compared with Group P. A possible consequence was the highest incidence of spinal deformities in Group L. At day $62 \mathrm{dph}$, the ossification was achieved and normal in $60 \%$ of the larvae in Group P, whereas this rate was only 13 and $19 \%$ in Groups C and L, respectively. The evaluation of probiotics should not be therefore limited to growth measurements, and should take into account ontogenetic chronology for improving larval quality with such treatments.
\end{abstract}

\section{Highlights :}

- The development of seabass larvae was affected by 2 dietary lactic acid bacteria $>$ Pediococcus acidilactici improved the rate of normal and complete ossification Lactobacillus casei increased the incidence of vertebral deformities - This was related to differences observed in gene expression of osteocalcin $\downarrow$ The 2 bacteria affected also differently the microbiota associated with the larvae

Keywords: Fish larvae ; Probiotics ; Microbiota ; Histopathology ; gene expression ; DGGE 


\section{Introduction}

Developmental conformation is a critical issue for fish hatcheries. Spinal deformities are particularly frequent, with many suspected causes, either physical, chemical, environmental, infectious, genetic or nutritional (Brown and Núñez, 1998). Consequently, many ways to limit these deformities have been proposed. Probiotics are applied to fish with positive effects on health and nutritional status, while antagonizing pathogenic bacteria. These treatments may be therefore useful to reduce some causes of skeletal deformation, and this was confirmed with several strains of probiotic lactic acid bacteria in rainbow trout, sea bass, and clownfish (Aubin et al., 2005; Frouël et al., 2008; Avella et al., 2010, Autin et al., 2012).

The interaction between dietary lactic acid bacteria and bone conformation is not clearly understood, and probably indirect. It may be related to the inhibition of pathogenic bacteria (Villamil et al., 2010). Probiotics may also stimulate the immune system, and reduce inflammation in fish larvae (Picchietti et al., 2009). Gil-martens (2010) suggested that local inflammation could affect the integrity of the spine, which would be thus exposed to a risk of deformation. Besides these pathological aspects, probiotics may improve many health factors that are essential for fish development in relation to either welfare (Rollo et al., 2006; Avella et al., 2010), digestion (Tovar-Ramírez et al., 2004; Frouël et al., 2008) or anti-oxidative status (Tovar-Ramírez et al., 2010).

Walter (2008) studied the role of lactobacilli in the mammalian intestinal tract, and concluded that allochthonous probiotic strains are particularly efficient for activating the immune system, even though they can hardly persist in the gut. A similar observation may apply to the intestine of fish, where allochthonous lactobacilli that modulate the immune response disappear soon after withdrawal from the diet (Panigrahi et al., 2005; Son et al., 2009). The selection of candidate probiotics from the host or from the local environment was however recommended to improve the potential for colonization and protection against pathogens 
(Verschuere et al., 2000). In the present experiment, two strains of lactic acid bacteria were incorporated in the dry diet that was used to feed sea bass from mouth opening onwards. The commercial strain of Pediococcus acidilactici was already tested with several fish species (Gatesoupe, 2002; Merrifield et al., 2009, 2010; Ferguson et al., 2010;), suggesting in particular some potential to alleviate vertebral deformities (Aubin et al., 2005; Autin et al., 2012). A strain of Lactobacillus casei was isolated from the local hatchery, and selected as candidate probiotic after characteristics of antagonism to pathogens, biofilm colonization, and gnotobiotic tests (Lamari et al., 2013; in preparation). The effects of the two strains were compared in regard to larval development and associated microbiota.

\section{Materials and methods}

\subsection{Larval rearing}

Two batches of sea bass larvae were allotted in two successive experiments at 1 day post hatch (dph) in 9 tanks of $35 \mathrm{~L}$ (3000 larvae/tank). The running water was not recycled in the rearing unit, and the water flow rate was progressively increased from $15 \mathrm{~L} \mathrm{~h}^{-1}$ at $5 \mathrm{dph}$ to 35 $\mathrm{L} \mathrm{h}^{-1}$ at $40 \mathrm{dph}$. The temperature was progressively increased from $17^{\circ} \mathrm{C}$ at $1 \mathrm{dph}$ to $20^{\circ} \mathrm{C}$ at $25 \mathrm{dph}$. The salinity was dropped to 28 practical salinity units (psu) during the start feeding period (7-13 dph), and then brought to the normal (35 psu). The larvae were kept in the dark until $4 \mathrm{dph}$, and then photoperiod was maintained at 18-6 light/dark from $4 \mathrm{dph}$ onwards. The light intensity was progressively increased from 10 to 200 lux between 4 and $25 \mathrm{dph}$, and then kept constant.

The diet was composed of 55\% fish meal, $12 \%$ fish protein hydrolysate (CPSP G), $20 \%$ soy lecithin, $8 \%$ vitamin mix (Gisbert et al., 2005), 4\% mineral mix (Gisbert et al., 2005), and 1\% betaine, on a dry matter basis. This basic composition was used for the control group C. 
Pediococcus acidilactici MA $18 / 5 \mathrm{M}$ was added to diet $\mathrm{P}$ in its dry commercial form (Bactocell@ PA10, Lallemand Inc.; Barreau et al., 2012). Lactobacillus casei X2, which was used for diet L, was cultivated on MRS broth, and harvested as pasty pellet after centrifuging at $4500 \mathrm{~g}$ for $30 \mathrm{~min}$. Each bacterial preparation was mixed with the dry components of diet $\mathrm{P}$ or L, after re-suspension in tap water. The same amount of water without bacterial suspension was used for control diet C. The final concentrations of probiotics were adjusted at $10^{6}$ and $10^{7} \mathrm{CFU}$ (Colony Forming Units) $\mathrm{g}^{-1}$ of the diet in Experiments 1 and 2, respectively, after air-drying at $45^{\circ} \mathrm{C}$. The three diets were ground and pelleted to a set of granulometric sizes suitable for each developmental stage (Cahu and Zambonino Infante, 2001). The pellets were stored at $4{ }^{\circ} \mathrm{C}$ until use, and then distributed continuously during the day light periods with automatic feeders. The amounts of $P$. acidilactici averaged $1.1 \times 10^{6}$ and $1.8 \times 10^{7} \mathrm{CFU} \mathrm{g}^{-1}$ in $\operatorname{diet} \mathrm{P}$, whereas diet $\mathrm{L}$ contained $L$. casei at the rate of $1.4 \times 10^{6}$ and $3.4 \times 10^{7} \mathrm{CFU} \mathrm{g}^{-1}$ in the two consecutive experiments, respectively, after counts on MRS-agar plates. The three diets were tested in triplicates in both experiments. In Experiment 1, the experimental diets were distributed from $10 \mathrm{dph}$ to the end (45dph). In Experiment 2, the larvae were fed the experimental diets from mouth opening ( $5 \mathrm{dph})$ to $41 \mathrm{dph}$, and then all the tanks were fed the control diet till the end (62 dph).

\subsection{Histological observations}

In experiment 2, the skeletal and chondro-osseous development was assessed on a total of 103 fish, with 15 or 16 individuals sampled per dietary group at 41 and $62 \mathrm{dph}$. The cartilaginous and bony tissue structures were distinguished by using the alcian blue-alizarin red double staining technique (Darias et al., 2010). Briefly, whole fish carcasses were fixed in $4 \%$ formalin for at least 24 hours. Alcian blue (Sigma) was used to stain the cartilage of 41 and 62 dph old larvae for $60 \mathrm{~min}$ and 24 hours, respectively, before neutralization for 3 min with a 
solution of $1 \% \mathrm{KOH}$ in ethanol. After rehydration, 1 volume $3 \% \mathrm{H}_{2} \mathrm{O}_{2}$ and 9 volumes $1 \%$ $\mathrm{KOH}$ were used to bleach the 41 and $62 \mathrm{dph}$ old larvae for 30 and $60 \mathrm{~min}$, respectively. After clearing in $30 \%$ sodium borate with $1 \mathrm{~g}$ trypsin (Sigma) for 20 hours, bone tissue was stained with alizarine red (Sigma) for 20 hours. The larvae were dehydrated and preserved in $100 \%$ glycerol.

Histopathological features, including inflammation, were evaluated on 20 fish sampled in each group at 20,41 and $62 \mathrm{dph}$ (162 fish in total). The tissue preparation and step sectioning were performed according to Spitsbergen et al. (2000). Briefly, whole fish carcasses were fixed in $4 \%$ formalin, after ventral incision of the abdomen of large individuals. Scales and fins were carefully removed, and the samples were dehydrated and embedded in paraffin. Serial sagittal step sections were cut from the left side of the fish. Four step sections from 62 dph old fish were mounted on glass slides, 1 from eye anterior chamber level, 1 from eye posterior chamber level, 1 just medial to the eye, and 1 at midline. Sections were routinely stained with Hematoxylin-Eosin-Saffron (HES).

\subsection{Osteocalcin Gene expression}

The method was described by Darias et al. (2010). The larvae were sampled at 20-22 dph for RNA extraction, as the most significant differences in gene expression were obtained at 22-23 dph in previous experiments. Larvae were also sampled at $41 \mathrm{dph}$ in Experiment 2. Between 200 and $350 \mathrm{mg}$ of fresh weight of larvae were collected from each tank for RNA extraction. Total RNA was reverse-transcribed (iScript cDNA Synthesis Kit, Bio-Rad Laboratories, Hercules, CA). Quantitative PCR were performed in triplicates in I-cycler with optical module (Bio-Rad), using a total volume of $15 \mu \mathrm{L}$ that contained $5 \mu \mathrm{L}$ cDNA (dilution, $10^{-2}$ ), $0.5 \mu \mathrm{L}$ primers $\left(10 \mu \mathrm{mol} \mathrm{L} \mathrm{L}^{-1}\right), 7.5 \mu \mathrm{L}$ iQ SYBR Green supermix $2 \times($ Bio-Rad), and $2 \mu \mathrm{L}$ sterile water. The PCR program consisted of an initial DNA denaturation of $94^{\circ} \mathrm{C}$ for $90 \mathrm{~s}$, 
followed by 45 cycles at $95^{\circ} \mathrm{C}$ for $30 \mathrm{~s}, 60^{\circ} \mathrm{C}$ for $60 \mathrm{~s}$ and 80 cycles at $95^{\circ} \mathrm{C}$ for $10 \mathrm{~s}$. The relative quantity of messenger was automatically normalized and measured with the software Bio-Rad IQ5, using Ef1 as housekeeping gene.

\subsection{Microbiological data}

The bacterial counts on Petrifilm aerobic count plates, TCBS and MRS agar were done as described previously (Gatesoupe, 2002) on sea bass at 18 and 45 dph in Experiment 1, and at 20, 30, and 40 dph in Experiment 2. At each date, 20 larvae were sampled in each tank, and pooled per tank before rinsing, homogenization, and dilution for plate counting.

In Experiment 2, larvae were sampled at 20 and $30 \mathrm{dph}$ for $\mathrm{BCP}$ (Bacterial Community Profile) analysis. At both dates, two sets of ten larvae were sampled and pooled per tank in 2 $\mathrm{mL}$ Eppendorf tubes. The first set was treated with $250 \mu \mathrm{L}$ of inhibiting buffer (4 M guanidine thiocyanate, $0.1 \mathrm{M}$ Tris, $\mathrm{pH} 7.5$ ) per tube, and stored at $-20^{\circ} \mathrm{C}$, waiting for DNA extraction and PCR-DGGE, as described previously (Gatesoupe et al., 2012). The second set was treated with $500 \mu \mathrm{L}$ Extract-All@ (Laboratoires Eurobio, Coutaboeuf, France) per tube, and stored at $-80^{\circ} \mathrm{C}$, waiting for RNA extraction. The method followed the instructions of the manufacturer for biological tissues, with an additional step of bead-beating for 10 minutes after the initial step of homogenization with a dispersing aggregate unit. The RNA was then stored at $-80^{\circ} \mathrm{C}$, and cDNA was transcribed from aliquots with the QuantiTect ${ }^{\circledR}$ reverse transcription kit (Qiagen). The PCR-DGGE protocol was then the same as for genomic DNA. PCR was performed to amplify the variable regions V6-V8 of the 16s ribosomal RNA gene. The PCR mix contained 2.5 $\mu \mathrm{M} \mathrm{MgCl}_{2}$ and primers Bact 968-GC-f (CGC CCG GGG CGC GCC CCG GGC GGG GCG GGG GCA CGG GGG GAA CGC GAA GAA CCT TAC; Nubel et al. 1996) and Bact 1401-r (CGG TGT GTA CAA GAC CC). After initial incubation at $94^{\circ} \mathrm{C}$ for 5 min, a 'touchdown' step was applied to the 10 first cycles by decreasing 
regularly the annealing temperature from 65 to $52^{\circ} \mathrm{C}$, and then the annealing temperature was maintained at $52^{\circ} \mathrm{C}$ during the 20 last cycles (denaturation at $94^{\circ} \mathrm{C}$ for $1 \mathrm{~min}$; annealing for 2 min; polymerisation at $72^{\circ} \mathrm{C}$ for $2 \mathrm{~min}$ ). The final extension lasted $30 \mathrm{~min}$ at $72^{\circ} \mathrm{C}$. The DGGE and image analyses were performed as described previously (Gatesoupe et al. 2012). The PCR products were analysed on two gels, which corresponded to the two dates of sampling. The larval samples were flanked on both sides with the PCR products from genomic DNA of pure cultures of the two probiotics. After DGGE, some bands corresponding to Operational Taxonomic Units (OTUs) were picked up from the gels, and treated as described previously (Silva et al., 2011). The final PCR products were cleaned up with GenElute (Sigma), and sequenced by MilleGen Biotechnologies (Labège, France).

\subsection{Statistics}

Growth data were compared with Kruskal-Wallis test for cases where the requirement of normality and equality of variance were not met, and with ANOVA when these requirements were met, allowing to group the tanks per diet by a priori F-test (Sokal and Rohlf, 2001). Post hoc pairwise comparisons were done with Tukey or Dunn's test, respectively. The ossification ranks were compared with Kruskal-Wallis test followed by Dunn test. The anatomopathological observations were classified in terms of incidence rates, which were compared between diets with $\chi^{2}$ or with Fisher's exact test when bins contained less than five individuals. The expression of osteocalcin gene, relative to Ef1, was compared with one-way ANOVA, and pairwise Student-Newman-Keuls test. The diversity indices were computed with the Paleontological Statistics Software Package (PAST; Hammer et al. 2001), and compared with two-way ANOVA. The similarity of BCPs was studied among the nine rearing tanks at the two dates of sampling with the Bray-Curtis indices, which were compared by 
two-way ANalysis Of Similarities (ANOSIM; Clarke 1993). The most dominant bands were classified depending on their contribution to dissimilarity with SIMilarity PERcentage (SIMPER; Clarke 1993). The overall average dissimilarity between two groups was computed as 1 minus the average of the inter-group Bray-Curtis similarity indices, multiplied by 100 .

\section{Results}

The survival of the larvae appeared in accordance with what is routinely observed with the rearing method, but it was not accurately quantified because of the great number of individuals that were picked up for sampling. The general levels of individual mean weights (Table 1) and lengths (Table 2) were higher in Experiment 1, compared to Experiment 2. The differences between dietary groups were not always significant, but the growth in the control group was generally lower than in the groups treated with lactic acid bacteria. In Experiment 1, the difference in mean length was significant between the control and the two other groups at 30 and $45 \mathrm{dph}$, and between Groups $\mathrm{C}$ and $\mathrm{L}$ at $22 \mathrm{dph}$. After log transformation, a twoway ANOVA indicated that the mean weights of the control group were significantly lower than those of the two other groups in the same experiment. In Experiment 2 at $20 \mathrm{dph}$, the growth in the control group was significantly lower than in the two other groups in terms of weight, but the difference was significant only between Groups $\mathrm{C}$ and $\mathrm{L}$ in terms of length. At 40 and $62 \mathrm{dph}$, there was no significant difference in growth between the three groups in Experiment 2 .

Among the larvae sampled at 20, 41, and 62 dph in Experiment 2, 17\% of the larvae from the control group exhibited spinal deformities. This rate was not significantly different from those observed in the two other groups, but the incidence in Group L was significantly higher than in Group P (28 and 11\%, respectively; Table 3). Spinal deformities were mostly observed at 
$62 \mathrm{dph}$, and appeared heterogeneous both in localization - cervical, lumbar and caudal - and in type of curvature (kyphosis, lordosis, and scoliosis). The histological features of notochord flexure were homogeneous, characterized by irregular-sized cells that were loosely associated in the flexure zones, leaving abnormal spaces in-between filled with amorphous eosinophilic material (Fig. 1). The mineralization process started hardly by $41 \mathrm{dph}$, with the first foci observed around the mouth and in the opercula (Fig. 2A). A significant delay in Group P was noted compared to the two other groups (Table 3). At 62 dph, the delay of Group P was overcome, and only 6 larvae had not completed normal mineralization among the 15 larvae studied in this group (Fig. $2 \mathrm{~B}$ and $2 \mathrm{C}$, Table 3). At the same time, the ossification was still largely incomplete, or even abnormal, in 13 of the 15 and 16 larvae of Groups C and L, respectively. The abnormal ossification observed in these two groups consisted in asynchronous development, as the vertebral axis and caudal fin rays were calcified, while the process was delayed in the other fin rays and in the skull. No lesion was noticed at $20 \mathrm{dph}$, but lesional foci appeared in muscle at $41 \mathrm{dph}$, and consisted in mononuclear infiltration surrounding isolated degenerating fibers (Fig. 3). At this stage, 5 of the 19 individuals of Group C showed signs of muscular inflammation, while this proportion was only of 1:19 and 2:20 in groups $\mathrm{P}$ and $\mathrm{L}$, respectively (Table 3 ). These figures were not sufficient to conclude about a hypothetical anti-inflammatory effect of the lactic acid bacteria, all the more as the incidence of inflammation reached 35-45\% at $62 \mathrm{dph}$, without significant difference between treatments (Table 3).

In both experiments, the gene coding for osteocalcin was overexpressed in group L at 20-22 dph (Table 4). This marker of ossification had the lowest levels of expression in Group P, and this was still the case at $41 \mathrm{dph}$ in Experiment 2.

The counts of aerobic bacteria on Petrifilms were generally not significantly different between treatments, except an overload at $45 \mathrm{dph}$ in the control group of Experiment 1 (Table 5). The 
same observation was done with TCBS agar counts, but no colony was detected at $18 \mathrm{dph}$ in Experiment 1 in the samples from Group L. The lactic acid bacteria - estimated with MRS agar counts - were not detected in the control group. In Experiment 1 with a low dosage of the probiotics, there was no colony on MRS agar at $18 \mathrm{dph}$, and the counts were at the threshold detection level at $45 \mathrm{dph}$. In Experiment 2, with a tenfold higher dosage of the probiotics, lactic acid bacteria were consistently retrieved in the plates corresponding to groups $\mathrm{P}$ and $\mathrm{L}$, and a significant difference was observed at $40 \mathrm{dph}$, indicating a higher survival of $L$. casei in the larvae, compared to P. acidilactici.

Between 5 and 25 bands were detected in the PCR and RT-PCR products deposited on the two DGGE gels corresponding to the larvae sampled at 20 and 30 dph in Experiment 2 (Fig. 4). The mean band richness was $15 \pm 4$, without significant differences between genomic DNA and cDNA, between date of sampling, and between diets. When the relative abundance was taken into account for the samples corresponding to genomic DNA, the 2-way ANOVA indicated an effect of the age of the larvae on the average BCP. The bands were more equitably distributed, with a higher Shannon's entropy, at $30 \mathrm{dph}$ compared with $20 \mathrm{dph}$ (Table 6). There was no significant difference with these indices for the RT-PCR products.

Based on Bray-Curtis index, there was a significant difference between the two dates of sampling in the 2-way analyses of similarity of the BCPs corresponding to PCR, and to RTPCR products (Table 7). In the same ANOSIM, the effect of the diet was significant with genomic DNA, but not with cDNA. The BCPs corresponding to the PCR products from Diet $\mathrm{P}$ were dissimilar from those of the two other diets, as illustrated by non-metric multidimensional scaling of the Bray-Curtis indices (Fig. 5). On the same representation, the effect of the date of sampling was also visible, while the BCPs corresponding to Diets $\mathrm{C}$ and $\mathrm{L}$ appeared similar at each date. 
A variety of Proteobacteria were identified after band isolation and sequencing (Fig. 4, Table 8). Most were $\gamma$-Proteobacteria, but there were also representatives of other classes $(\alpha-, \delta$-, and $\varepsilon$-Proteobacteria). Figure 6 illustrate the mean relative abundances of the seven main bands that accounted for the pairwise dissimilarities between groups of BCPs, according to SIMPER analysis. At $20 \mathrm{dph}$, the overall average dissimilarity observed between Diets C and L was lower than between $\mathrm{C}$ and P (Table 9). At the same date, Vibrio sp. G was detected only in the group corresponding to the PCR products from Diet P, while it was evenly distributed among the RT-PCR products. Vibrio sp. A was detected only at $20 \mathrm{dph}$, and the two OTUs $G$ and A were the main contributors for dissimilarity between most pairwise comparisons concerning $20 \mathrm{dph}$ (Tables 9 and 10). At $30 \mathrm{dph}$, the band that migrated to the same Rf as L. casei X2 (0.835) was mainly represented in the group corresponding to Diet L for cDNA. That might indicate a strong activity of the probiotic strain in Group L, but the same band was also observed with the two other diets. After band excision, the reamplification of the PCR product failed, and no sequence was available for this Rf. This unidentified band was the most dissimilar for pairwise comparisons concerning cDNA, and Diets $\mathrm{C}$ or L at $30 \mathrm{dph}$. Vibrio sp. O, Alteromonas sp., Arcobacter sp., and the unidentified band $\mathrm{U}$ (Rf 0.773) were also the main contributors for dissimilarity in some other comparisons at $30 \mathrm{dph}$ (Tables 9 and 10). P. acidilactici had the same $\mathrm{Rf}$ as an $\alpha$ Proteobacterium, but the band was never among the most abundant.

\section{Discussion}

The tenfold increase of the dose of probiotics between the two experiments was decided because of the low recovery of lactic acid bacteria in the first experiment. This change boosted the level of lactic acid bacteria above the detection threshold in the experimental groups, but it may be suspected to have caused partly the differences in the effects of the 
treatments that were observed between the two experiments. The dose is an important factor for the efficiency of probiotics (Nikoskelainen et al., 2003; Tovar et al., 2004), and further investigation is needed to document the dose responses in fish. The counts of lactic acid bacteria remained at a low level in the larvae, even in the second experiment, indicating that the dietary addition of the two strains did not induce gut colonization.

Rollo et al. (2006) reported a reduction of the total bacterial counts in sea bream larvae due to the probiotics. Another strain of $P$. acidilactici inhibited in vitro the growth of pathogenic Vibrio splendidus (Villamil et al., 2010). The inhibitory effect of the present probiotic treatments was not visible on total bacterial counts, except at $45 \mathrm{dph}$ in the first experiment. Considering the microbial profiles associated with sea bass larvae, the dominant phylotypes of Vibrio were different between the group fed P. acidilactici and the two other dietary groups. The same strain of $P$. acidilactici affected also the bacterial profiles observed in ongrowing red tilapia, and the probiotic seemed to remain among the dominant phylotypes, even several days after reverting to the control diet (Ferguson et al., 2010). P. acidilactici survived in sea bass larvae in the present experiments, but it remained slightly above the plate counting threshold. The probiotic strain was not detectable in the bacterial profiles obtained by DGGE, especially as another operational taxonomic unit migrated as the same position. L. casei did not affect significantly the microbial community, but its level in the larvae appeared higher compared with $P$. acidilactici, at least at $40 \mathrm{dph}$ with the high dietary dosage. At this stage, there was a strong dominance of the corresponding band on the lawns with RT-PCR products from the group fed with L. casei. That may indicate that the strain was active in the larvae, but another unidentified taxonomic unit migrated at the same place, and this band was also present in the two other dietary groups. Navarrete et al. (2012) emphasized the interest of using RNA-based profiling of microbial communities to highlight the phylotypes with high transcriptional activity. However in the present experiment, the effect of P. acidilactici on the 
microbial community was evident when comparing the profiles obtained with genomic DNA, but less clear with those obtained from the RT-PCR products. The differences observed between the profiles at 20 and 30 dph illustrated the time course fluctuation within microbiota associated with the larvae, especially with cDNA. The information obtained from genomic DNA is likely less dependent on short-term variability in bacterial activity, compared to the RNA-based data.

In both experiments, the growth of sea bass larvae was stimulated by the addition of the two lactic acid bacteria, especially during the first fortnight of feeding. However, this stimulation was not similar with the two experimental treatments. The diet with L. casei X2 induced the overexpression of osteocalcin at 20-22 dph in both experiments, while the mineralization process was slowed down with $P$. acidilactici MA $18 / 5 \mathrm{M}$ at this sampling point. At the end of the second experiment, a high incidence of spinal deformities was visible with L. casei, whereas not only was the delay in mineralization overcome with $P$. acidilactici, but the achievement of skeletal conformation reached a better score than with L. casei. It seems therefore that the two lactic acid bacteria influenced indirectly bone mineralization in different ways, possibly involving the mechanisms of $\mathrm{Ca}^{2+}$ absorption at the time of vertebral column ossification (around 22 dph; Darias et al., 2011). The same strain of $P$. acidilactici was introduced as probiotic additive in the compound diet of rainbow trout, and this treatment reduced the incidence of the vertebral compression syndrome (Aubin et al., 2005). A reduction in spinal deformities of sea bass fry, specifically lordosis, was also recently reported with the same strain in a commercial hatchery in Greece (Autin et al., 2012). The conformation of sea bass juveniles was improved with another probiotic mixture of lactobacilli (Frouël et al., 2008). Several lactic acid bacteria seem exert a beneficial regulation on bone development in fish, but not all, as exemplified with L. casei X2. In-depth studies 
appear thus required to qualify candidate probiotics, beyond a general effect on growth stimulation.

These experiments confirmed the interest of the allochthonous probiotic P. acidilactici for improving skeletal conformation in fish, even though the mode of action remains to be elucidated. The trend to reduce inflammation was not significant, and more numerous observations are required to evaluate the relevance of the hypothesis of Gil-martens (2010) in this particular case. If confirmed, the protective effect against inflammation may be related to the effect of the probiotic on gut microbiota, whose consequences on bone development should be further explored. That may open up several tracks of investigation, like the blockage of release of bacterial toxins that disturb intestinal absorption (Laohachai et al., 2003), or the prevention of bacterial infections that affect calcium homeostasis (Crouser and Dorinsky, 1996).

\section{Acknowledgements}

The authors would like to thank for financial supports EGIDE (CMCU project France-Tunisia No. 08G 0907), and the Agence Universitaire de la Francophonie (AUF-PSCI No. 6313PS809).

\section{References}

Aubin J., Gatesoupe F.J., Labbé L., Lebrun L., 2005. Trial of probiotics to prevent the vertebral column compression syndrome in rainbow trout (Oncorhynchus mykiss Walbaum). Aquac. Res. 36, 758-767. doi:10.1111/j.1365-2109.2005.01280.x. 
Autin, M., Ntomalis, K., Castex, M., 2012. Effect of probiotic Pediococcus acidilacticci MA 18/5M (Bactocell ${ }^{\circledR}$ ) on seabass Dicentrachus labrax vertebral deformities. In: "Aqua 2012: Global Aquaculture - Securing our Future", abstracts of the papers presented at the WASEAS Conf., Prague, Czech Republic, Sept. 1-5 2012.

Avella, M.A., Olivotto, I., Silvi, S., Place, A.R., Carnevali, O., 2010. Effect of dietary probiotics on clownfish: a molecular approach to define how lactic acid bacteria modulate development in a marine fish. Am. J. Physiol.-Reg. I. 298, R359-R371. doi:10.1152/ajpregu.00300.2009.

Barreau, G., Tompkins, T.A., de Carvalho, V.G., 2012. Draft genome sequence of probiotic strain Pediococcus acidilactici MA18/5M. J. Bacteriol. 194, 901-901. doi: 10.1128/jb.0656311

Brown, C.L., Núñez, J.M., 1998. Disorders of development. In: Leatherland, J.F., Woo, P.T.K. (Eds.), Fish Diseases and Disorders, Volume 2: Non-infectious Disorders. CAB International, Wallingford, UK, pp. 1-17.

Cahu, C., Zambonino Infante, J. (2001). Substitution of live food by formulated diets in marine fish larvae. Aquaculture 200, 161-180. doi:10.1016/S0044-8486(01)00699-8.

Clarke, K.R.; 1993. Non-parametric multivariate analysis of changes in community structure. Aust. J. Ecol. 18, 117-143. doi: 10.1111/j.1442-9993.1993.tb00438.x 
Crouser, E.D., Dorinsky, P.M., 1996. Metabolic consequences of sepsis: correlation with altered intracellular calcium homeostasis. Clin. Chest Med. 17, 249-261.

Darias, M.J., Wing, O.L.C., Cahu, C., Zambonino-Infante, J.L., Mazurais, D., 2010. Double staining protocol for developing European sea bass (Dicentrarchus labrax) larvae. J. Appl. Ichthyol. 26, 280-285. doi:10.1111/j.1439-0426.2010.01421.x.

Darias, M.J., Mazurais, D., Koumoundouros, G., Cahu, C.L., Zambonino-Infante, J.L., 2011. Overview of vitamin D and C requirements in fish and their influence on the skeletal system. Aquaculture, 2011. 315, 49-60.doi:10.1016/j.aquaculture.2010.12.030.

Ferguson, R.M.W., Merrifield, D.L., Harper, G.M., Rawling, M.D., Mustafa, S., Picchietti, S., Balcázar, J.L., Davies, S.J., 2010. The effect of Pediococcus acidilactici on the gut microbiota and immune status of on-growing red tilapia (Oreochromis niloticus). J. Appl. Microbiol. 109, 851-862. doi:10.1111/j.1365-2672.2010.04713.x.

Frouël, S., Le Bihan, E., Serpentini, A., Lebel, J.M., Koueta, N., Nicolas, J.L., 2008. Preliminary study of the effects of commercial lactobacilli preparations on digestive metabolism of juvenile sea bass (Dicentrarchus labrax) J. Mol. Microbiol. Biotechnol. 14, 100-106. doi:10.1159/000106088.

Gatesoupe, F.J., 2002. Probiotic and formaldehyde treatments of Artemia nauplii as food for larval pollack, Pollachius pollachius. Aquaculture 212, 347-360. doi:10.1016/S00448486(02)00138-2. 
Gatesoupe, F.J., Covès, D., Ortega, A., Papandroulakis, N., Vadstein, O., de la Gándara, F., 2012. A spatio-temporal study of bacterial community profiles associated with Atlantic bluefin tuna larvae, Thunnus thynnus L., in three Mediterranean hatcheries. Aquac. Res. (early view) doi: 10.1111/j.1365-2109.2012.03158.x.

Gil-Martens, L., 2010. Inflammation as a potential risk factor for spinal deformities in farmed Atlantic salmon (Salmo salar L.). J. Appl. Ichthyol. 26, 350-354. doi:10.1111/j.14390426.2010.01433.x.

Gisbert E., Villeneuve L., Zambonino J.L., Quazuguel P., Cahu C., 2005. Dietary phospholipids are more efficient than neutral lipids for long-chain polyunsaturated fatty acid supply in European sea bass Dicentrarchus labrax larval development. Lipids 40, 609-618. doi:10.1007/s11745-005-1422-0.

Hammer, Ø., Harper, D.A.T., Ryan, P.D., 2001. PAST: Paleontological Statistics Software Package for Education and Data Analysis. Palaeontologia Electronica 4, 9 pp. http://palaeoelectronica.org/2001_1/past/issue1_01.htm. Accessed 2 May 2012

Lamari, F., Bakhrouf, A., Gatesoupe, F.J., 2012. Identification, caractérisation biochimique et moléculaire des souches de bactéries lactiques a effet anti-vibrios. In : 7ème Congrès international «Qualité des Produits et de l'Environnement : Traitement et Valorisation des Rejets et Effets sur la Santé Humaine, QPE-TVR 2012 », 20-22 April 2012, Mahdia, Tunisia. 
Laohachai, K.N., Bahadi, R., Hardo, M. B., Hardo, P. G., Kourie, J. I., 2003. The role of bacterial and non-bacterial toxins in the induction of changes in membrane transport: implications for diarrhea. Toxicon 42, 687-707. doi:10.1016/j.toxicon.2003.08.010.

Merrifield, D.L., Bradley, G., Harper, G.M., Baker, R.T.M., Munn, C.B., Davies, S.J., 2009. Assessment of the effects of vegetative and lyophilized Pediococcus acidilactici on growth, feed utilization, intestinal colonization and health parameters of rainbow trout (Oncorhynchus mykiss Walbaum). Aquac. Nutr. 17, 73-79. doi:10.1111/j.1365-2095.2009.00712.x.

Merrifield, D.L., Harper, G.M., Dimitroglou, A., Ring $\varnothing$, E., Davies, S.J., 2010. Possible influence of probiotic adhesion to intestinal mucosa on the activity and morphology of rainbow trout (Oncorhynchus mykiss) enterocytes. Aquac. Res. 41, 1268-1272. doi:10.1111/j.1365-2109.2009.02397.x.

Navarrete, P., Magne, F., Araneda, C., Fuentes, P., Barros, L., Opazo, R., Espejo, R., Romero, J., 2012. PCR-TTGE analysis of $16 \mathrm{~S}$ rRNA from rainbow trout (Oncorhynchus mykiss) gut microbiota reveals host-specific communities of active bacteria. PLoS One 7, e31335. doi:10.1371/journal.pone.0031335.

Nikoskelainen, S., Ouwehand, A.C., Bylund, G., Salminen, S., Lilius, E.M., 2003. Immune enhancement in rainbow trout (Oncorhynchus mykiss) by potential probiotic bacteria (Lactobacillus rhamnosus). Fish Shellfish Immunol. 15, 443-452. doi:10.1016/S10504648(03)00023-8. 
Panigrahi, A., Kiron, V., Puangkaew, J., Kobayashi, T., Satoh, S., Sugita, H., 2005. The viability of probiotic bacteria as a factor influencing the immune response in rainbow trout Oncorhynchus mykiss. Aquaculture 243, 241-254. doi:10.1016/j.aquaculture.2004.09.032.

Picchietti, S., Fausto, A.M., Randelli, E., Carnevali, O., Taddei, A.R., Buonocore, F., Scapigliati, G., Abelli, L. 2009. Early treatment with Lactobacillus delbrueckii strain induces an increase in intestinal T-cells and granulocytes and modulates immune-related genes of larval Dicentrarchus labrax (L.). Fish Shellfish Immun. 26, 368-376. doi:10.1016/j.fsi.2008.10.008.

Rollo, A., Sulpizio, R., Nardi, M., Silvi, S., Orpianesi, C., Caggiano, M., Cresci, A., Carnevali, O., 2006. Live microbial feed supplement in aquaculture for improvement of stress tolerance. Fish Physiol. Biochem. 32, 167-177. doi:10.1007/s10695-006-0009-2.

Silva, F.C.P., Nicoli, J.R., Zambonino-Infante, J.L., Kaushik, S., Gatesoupe, F.J., 2011. Influence of the diet on the microbial diversity of faecal and gastrointestinal contents in gilthead sea bream (Sparus aurata) and intestinal contents in goldfish (Carassius auratus). FEMS Microbiol. Ecol. 78, 285-296. doi:10.1111/j.1574-6941.2011.01155.x.

Sokal, R. R., Rohlf, F. J., 2001. Biometry: The principles and practice of statistics in biological research, 3rd ed. W. H. Freeman.

Son, V.M., Chang, C.C., Wu, M.C., Guu, Y.K., Chiu, C.H., Cheng, W., 2009. Dietary administration of the probiotic, Lactobacillus plantarum, enhanced the growth, innate 
immune responses, and disease resistance of the grouper Epinephelus coioides. Fish Shellfish Immunol. 26, 691-698. doi: 10.1016/j.fsi.2009.02.018.

Spitsbergen, J.M., Tsai, H., Reddy, A., Miller, T., Arbogast, D., Hendricks, J.D., Bailey, G.S., 2000. Neoplasia in zebrafish (Danio rerio) treated with 7,12-diniethylbenz[a]anthracene by two exposure routes at different developmental stages. Toxicol. Pathol. 28, 705-715. doi:10.1177/019262330002800511.

Tovar-Ramírez, D., Zambonino Infante, J.Z., Cahu, C., Gatesoupe, F.J., Vázquez-Juárez, R., 2004. Influence of dietary live yeast on European sea bass (Dicentrarchus labrax) larval development. Aquaculture 234, 415-427. doi:10.1016/j.aquaculture.2004.01.028.

Tovar-Ramírez, D., Mazurais, D., Gatesoupe, F.J., Quazuguel, P., Cahu, C.L., ZamboninoInfante, J.L., 2010. Dietary probiotic live yeast modulates antioxidant enzyme activities and gene expression of sea bass (Dicentrarchus labrax) larvae. Aquaculture 300, 142-147. doi.org/10.1016/j.aquaculture.2009.

Verschuere L., Rombaut G., Sorgeloos P., Verstraete W., 2000. Probiotic bacteria as biological control agents in aquaculture. Microbiol. Mol. Biol. Rev. 64, 655-671. doi:10.1128/MMBR.64.4.655-671.2000.

Villamil, L., Figueras, A., Planas, M., Novoa, B., 2010. Pediococcus acidilactici in the culture of turbot (Psetta maxima) larvae: Administration pathways. Aquaculture 307, 83-88. doi:10.1016/j.aquaculture.2010.07.004. 
Walter, J., 2008. Ecological role of lactobacilli in the gastrointestinal tract: implications for fundamental and biomedical research. Appl. Environ. Microbiol. 74, 4985-4996. doi:10.1128/aem.00753-08. 


\section{Figure captions}

Figure 1 - Sagittal sections stained with haemalun-eosine-saffron of sea bass larvae (62 dph) in Experiment 2: $1 \mathrm{~A}$ - Normal aspect of the vertebral axis; $2 \mathrm{~A}$ - magnification of spinal deformity: notochord cells are irregularly sized and lakes of eosinophilic material is present in-between

Figure 2 - Alcian blue-alizarin red double stained sea bass larvae in Experiment 2: 2A - larva at $41 \mathrm{dph}$ with first signs of calcification around the mouth and in the opercula (rank 2, see footnote in Table 3); 2B - larva at 62 dph with intermediate skeletal development stage (rank 8); $2 \mathrm{C}$ larva at $62 \mathrm{dph}$ with ossification almost completed (rank 10).

Figure 3 - Lesional focus in muscle. Muscular fiber appeared necrotic and surrounded by numerous mononuclear inflammatory cells in sea bass larvae at $62 \mathrm{dph}$ in Experiment 2.

Figue 4 - Alignment of two DGGE gels of the PCR and RT-PCR products obtained obtained from pools of 10larvae at $20 \mathrm{dph}$ and $30 \mathrm{dph}$ in each tank of Experiment 2 (three tanks per treatment). The PCR products obtained from pure cultures of Lactobacillus casei X2 (L) and Pediococcus acidilactici (P) were added at the extremities of the two gels. The other letters indicate the position of the OTUs identified (letter at the left of the corresponding OTU described in Table 8)

Figure 5 - Non- metric multidimensional scaling, based on the 2-way ANOSIM on BrayCurtis indices of BCPs from PCR products. The filled and open symbols correspond to the BCPs at 20 and $30 \mathrm{dph}$, respectively; the circles, squares and triangles correspond to Diets $\mathrm{C}$, $\mathrm{L}$ and $\mathrm{P}$, respectively; the lines join the triplicates per condition (Age $\times$ Diet).

Figure 6 - Mean relative abundances of the dominant bands at 20 and 30 dph in the BCPs corresponding to PCR and RT-PCR products from samples of larvae fed one of the 3 diets in Experiment 2; Lactobacillus casei X2 (L) had the same Rf as unidentified OTU (0.835). 


\section{Table 1}

Mean weights of sea bass larvae fed the three diets (mg \pm Standard Error, SE). Superscript letters indicated significant differences between dietary groups at the same date and in the same experiment. The data were compared with one-way ANOVA followed by Tukey multiple comparison test, or with Kruskal-Wallis test (KW) followed by Dunn test. The type of test used depended on the normality and the equality of variance assumptions for the parametric tests. $P$ levels are indicated with asterisks (n.s., not significant). For each comparison, the means without common superscript are significantly different.

\begin{tabular}{lcccc}
\hline Diet & $\mathrm{C}$ & $\mathrm{P}$ & $\mathrm{L}$ & ANOVA \\
\hline Experiment 1 & & & & \\
$22 \mathrm{dph}$ & $0.99 \pm 0.10$ & $1.11 \pm 0.08$ & $1.23 \pm 0.05$ & n.s. ${ }^{\S}$ \\
$30 \mathrm{dph}$ & $2.56 \pm 0.21$ & $3.29 \pm 0.42$ & $3.54 \pm 0.46$ & n.s. \\
$45 \mathrm{dph}$ & $21.33 \pm 1.69$ & $24.17 \pm 0.17$ & $25.00 \pm 0.76$ & n.s. \\
Experiment 2 & & & & \\
$20 \mathrm{dph}$ & $0.79^{\mathrm{b}} \pm 0.05$ & $0.97^{\mathrm{a}} \pm 0.10$ & $0.93^{\mathrm{a}} \pm 0.04$ & $*(\mathrm{KW})$ \\
$40 \mathrm{dph}$ & $17.19 \pm 0.81$ & $17.37 \pm 0.67$ & $17.68 \pm 0.68$ & n.s. $(\mathrm{KW})$ \\
$62 \mathrm{dph}$ & $42.9 \pm 3.7$ & $53.1 \pm 5.3$ & $50.5 \pm 1.4$ & n.s. $(\mathrm{KW})$
\end{tabular}

$\S$ Two-way ANOVA after log transformation: significant differences between Ages*** and Diets* ( $\mathrm{C}$ different from $\mathrm{P}$ and $\mathrm{L}$ ), interaction not significant. 


\section{Table 2}

Mean total lengths of sea bass larvae fed the three diets ( $\mathrm{mm} \pm \mathrm{SE}$ ). Superscript letters indicated significant differences between dietary groups at the same date and in the same experiment. The data were compared with one-way ANOVA followed by Tukey multiple comparison test, or with Kruskal-Wallis test (KW) followed by Dunn test. The type of test used depended on the normality and the equality of variance assumptions for the parametric tests. $P$ levels are indicated with asterisks (n.s., not significant). For each comparison, the means without common superscript are significantly different. The tanks were grouped per diet, and the means were compared by a priori $F$-test, when applicable, according to Sokal and Rohlf (2001; n.a., not applicable).

\begin{tabular}{lccccc}
\hline Diet & $\mathrm{C}$ & $\mathrm{P}$ & $\mathrm{L}$ & ANOVA & a priori $F$-test \\
\hline Experiment 1 & & & & & \\
$22 \mathrm{dph}$ & $6.82^{\mathrm{b}} \pm 0.13$ & $7.16^{\mathrm{b}} \pm 0.12$ & $7.65^{\mathrm{a}} \pm 0.12$ & $* * *$ & $* * *$ \\
$30 \mathrm{dph}$ & $7.24^{\mathrm{b}} \pm 0.20$ & $8.48^{\mathrm{a}} \pm 0.19$ & $8.96^{\mathrm{a}} \pm 0.26$ & $* * *$ & $* * *$ \\
$45 \mathrm{dph}$ & $15.86^{\mathrm{b}} \pm 0.69$ & $19.04^{\mathrm{a}} \pm 0.29$ & $19.55^{\mathrm{a}} \pm 0.23$ & $* * *$ & $* * *$ \\
Experiment 2 & & & & & \\
20 dph & $6.64^{\mathrm{b}} \pm 0.07$ & $6.83^{\mathrm{ab}} \pm 0.08$ & $7.00^{\mathrm{a}} \pm 0.08$ & $* * *(\mathrm{KW})$ & n.a. \\
$40 \mathrm{dph}$ & $13.87 \pm 0.16$ & $14.18 \pm 0.17$ & $14.37 \pm 0.17$ & n.s. & $*$ \\
$62 \mathrm{dph}$ & $18.21 \pm 0.40$ & $19.45 \pm 0.55$ & $19.35 \pm 0.45$ & n.s. $(\mathrm{KW})$ & n.a. \\
\hline
\end{tabular}




\section{Table 3}

Incidence rates of anatomopathological features observed in the larvae in Experiment 2; the data of vertebral deformities cumulated the observations at 20,41 and $62 \mathrm{dph}$; the average stage of mineralization ${ }^{\S}$ was compared between diets at 41 and 62 dph with Kruskal-Wallis test followed by Dunn test; at $62 \mathrm{dph}$, the individuals with complete and normal ossification were counted in each group; no inflammation was observed at $20 \mathrm{dph}$, but only at 41 and 62 dph. The $\chi^{2}$ test was replaced by Fisher's exact test when bins contained less than five individuals (significance level indicated by stars; n.s. : not significant). Superscript letters indicated significant differences between dietary groups.

\begin{tabular}{|c|c|c|c|}
\hline Diet & $\mathrm{C}$ & $\mathrm{P}$ & $\mathrm{L}$ \\
\hline Conformation (total number of larvae obse & to & 56 & 50 \\
\hline Incidence rate of vertebral deformities & $0.17^{\mathrm{ab}}$ & $0.11^{\mathrm{b}}$ & $0.28^{\mathrm{a}}$ \\
\hline Comparison with Group L ( $\chi^{2}$ probability) & 0.22 n.s. & $0.02 *$ & - \\
\hline \multicolumn{4}{|l|}{ Mineralization at $41 \mathrm{dph}$} \\
\hline Total number of larvae observed & & 16 & 15 \\
\hline Average rank of ossification $\$$ & $2.5^{\mathrm{a}} \pm 0.3$ & $1.6^{\mathrm{b}} \pm 0.2$ & $2.6^{\mathrm{a}} \pm 0.2$ \\
\hline \multicolumn{4}{|l|}{ Mineralization at $62 \mathrm{dph}$} \\
\hline Average rank of ossification (abnormal cases excluded) ${ }^{\S}$ & $6.6 \pm 0.7$ & $7.6 \pm 0.8$ & $6.8 \pm 0.8$ \\
\hline Number of larvae with abnormal mineralization & 3 & 0 & 4 \\
\hline Total number of larvae observed & 15 & 15 & 16 \\
\hline Incidence rate of incomplete or abnormal mineralization & $0.87^{\mathrm{a}}$ & $0.40^{\mathrm{b}}$ & $0.81^{\mathrm{a}}$ \\
\hline Comparison with Group P (Fisher exact probability) & $0.03 *$ & - & $0.03 *$ \\
\hline Inflammation at $41 \mathrm{dph}$ (number of larvae observed) & 19 & 20 & 20 \\
\hline Incidence rate of inflammatory lesions & 0.26 & 0.05 & 0.10 \\
\hline Comparison with Group C (Fisher exact probability) & - & 0.09 n.s. & 0.24 n.s. \\
\hline Inflammation at $62 \mathrm{dph}$ (number of larvae observed) & 20 & 20 & 20 \\
\hline Incidence rate of inflammatory lesions & 0.45 & 0.35 & 0.40 \\
\hline
\end{tabular}

${ }^{\S}$ Ranking per stage of ossification: (1) none; (2) mouth and opercula; (3) several cranial foci; (4) $1^{\text {st }}$ vertebrae; (5) $1 / 2$ vertebral column; (6) $3 / 4$ vertebral column; (7) caudal fin rays; (8) rays in several fins; (9) dorsal, pelvic, anal, and pectoral fin rays; (10) complete mineralization (see Fig. 2) 


\section{Table 4}

Relative expression of osteocalcin gene in sea bass larvae fed the three experimental diets at 20-22 dph in the two consecutive experiments, and at $41 \mathrm{dph}$ in Experiment 2. The arbitrary units, relative to Ef1, were compared by one-way ANOVA, and pairwise Student-NewmanKeuls test. The significant differences are indicated by different superscript letters after the means in the same row ( \pm standard deviation).

\begin{tabular}{lccc}
\hline Diet & $\mathrm{C}$ & $\mathrm{P}$ & $\mathrm{L}$ \\
\hline 22 dph (Experiment 1) & $0.85^{\mathrm{ab}} \pm 0.13$ & $0.73^{\mathrm{b}} \pm 0.14$ & $1.70^{\mathrm{a}} \pm 0.38$ \\
$20 \mathrm{dph}$ (Experiment 2) & $0.77^{\mathrm{b}} \pm 0.08$ & $0.66^{\mathrm{b}} \pm 0.02$ & $1.16^{\mathrm{a}} \pm 0.04$ \\
\hline 41 dph (Experiment 2) & $1.54^{\mathrm{a}} \pm 0.35$ & $0.56^{\mathrm{b}} \pm 0.16$ & $1.12^{\mathrm{ab}} \pm 0.22$ \\
\hline
\end{tabular}


Table 5

Mean amounts of bacteria associated with seabass larvae counted on three culture media: Petrifilm for aerobes, TCBS, and MRS (CFU larva ${ }^{-1}, \log$ value \pm SE). Superscript letters indicated significant differences between dietary groups at the same date and in the same experiment (n.d.: not detected).

\begin{tabular}{|c|c|c|c|c|c|c|c|c|c|}
\hline \multirow{2}{*}{$\begin{array}{l}\text { Medium } \\
\text { Diet }\end{array}$} & \multicolumn{3}{|c|}{ Petrifilm } & \multicolumn{3}{|c|}{ TCBS } & \multicolumn{3}{|c|}{ MRS } \\
\hline & $\mathrm{C}$ & $\mathrm{P}$ & $\mathrm{L}$ & $\mathrm{C}$ & $\mathrm{P}$ & & $\mathrm{C}$ & $\mathrm{P}$ & $\mathrm{L}$ \\
\hline $\begin{array}{l}18-20 \mathrm{dph} \\
\text { Experiment } \\
1\end{array}$ & $\begin{array}{c}3.42 \pm \\
0.49\end{array}$ & $\begin{array}{c}2.75 \pm \\
0.00\end{array}$ & $\begin{array}{c}3.16 \pm \\
0.08\end{array}$ & $\begin{array}{c}1.35 \pm \\
1.35\end{array}$ & $\begin{array}{c}1.42 \pm \\
1.42\end{array}$ & n.d. & n.d. & n.d. & n.d. \\
\hline $\begin{array}{l}\text { Experiment } \\
2\end{array}$ & $\begin{array}{c}3.43 \pm \\
0.53\end{array}$ & $\begin{array}{c}3.33 \pm \\
0.09\end{array}$ & $\begin{array}{c}3.87 \pm \\
0.30\end{array}$ & $\begin{array}{c}2.58 \pm \\
0.60\end{array}$ & $\begin{array}{c}2.74 \pm \\
0.18\end{array}$ & $\begin{array}{c}2.52 \pm \\
0.17\end{array}$ & n.d. & $\begin{array}{c}0.55 \pm \\
0.20\end{array}$ & $\begin{array}{c}1.21 \pm \\
0.55\end{array}$ \\
\hline $\begin{array}{l}30 \mathrm{dph} \\
\text { Experiment } \\
2\end{array}$ & $\begin{array}{c}3.75 \pm \\
0.56\end{array}$ & $\begin{array}{c}3.45 \pm \\
0.32\end{array}$ & $\begin{array}{c}2.86 \pm \\
0.28\end{array}$ & $\begin{array}{c}3.01 \pm \\
0.69\end{array}$ & $\begin{array}{c}2.10 \pm \\
1.09\end{array}$ & $\begin{array}{c}0.86 \pm \\
0.86\end{array}$ & n.d. & $\begin{array}{c}1.54 \pm \\
0.27\end{array}$ & $\begin{array}{c}1.49 \pm \\
0.11\end{array}$ \\
\hline $\begin{array}{l}40-45 \mathrm{dph} \\
\text { Experiment } \\
1\end{array}$ & $\begin{array}{c}4.68^{\mathrm{a}} \\
\pm 0.31\end{array}$ & $\begin{array}{c}3.37^{\mathrm{b}} \pm \\
0.18\end{array}$ & $\begin{array}{c}3.42^{\mathrm{b}} \\
\pm 0.31\end{array}$ & $\begin{array}{c}3.25^{\mathrm{a}} \\
\pm 0.50\end{array}$ & $\begin{array}{l}1.50^{\mathrm{b}} \\
\pm 0.10\end{array}$ & $\begin{array}{c}1.67^{\mathrm{b}} \\
\pm 0.33\end{array}$ & n.d. & -0.02 & $\begin{array}{c}0.04 \pm \\
0.22\end{array}$ \\
\hline $\begin{array}{l}\text { Experiment } \\
2\end{array}$ & $\begin{array}{c}2.45 \pm \\
0.20\end{array}$ & $\begin{array}{c}2.87 \pm \\
0.59\end{array}$ & $\begin{array}{c}2.47 \pm \\
0.06\end{array}$ & $\begin{array}{c}1.44 \pm \\
0.72\end{array}$ & $\begin{array}{c}0.51 \pm \\
0.51\end{array}$ & $\begin{array}{c}1.66 \pm \\
0.22\end{array}$ & n.d. & $\begin{array}{c}1.50^{\mathrm{b}} \pm \\
0.18\end{array}$ & $\begin{array}{c}2.34^{\mathrm{a}} \pm \\
0.24\end{array}$ \\
\hline
\end{tabular}




\section{Table 6}

Two-way ANOVA of diversity indices of BCPs corresponding to PCR products from samples of larvae fed one of the 3 diets at 20 and $30 \mathrm{dph}$ in Experiment 2. $P$ levels are indicated with asterisks (n.s., not significant). The least square means were indicated per date of sampling, as they were significantly different.

\begin{tabular}{lcllcll}
\hline 2-way ANOVA on Shannon's entropy & \multicolumn{4}{c}{ 2-way ANOVA on equitability } \\
\hline Factor Age $(P)$ & 0.008 & $* *$ & & Factor Age $(P)$ & 0.015 & $*$ \\
Factor Diet $(P)$ & 0.41 & n.s. & Factor Diet $(P)$ & 0.40 & n.s. \\
Interaction $(P)$ & 0.64 & n.s. & Interaction $(P)$ & 0.96 & n.s. \\
Least square means for Age & & & & & \\
$20 \mathrm{dph}$ & $2.02 \pm 0.10$ & & $0.79 \pm 0.02$ & \\
$30 \mathrm{dph}$ & $2.46 \pm 0.10$ & & $0.87 \pm 0.02$ & \\
\hline
\end{tabular}




\section{Table 7}

Two-way ANOSIM on Bray-Curtis indices of the BCPs corresponding to PCR and RT-PCR products from samples of larvae fed one of the 3 diets at 20 and $30 \mathrm{dph}$ in Experiment $2\left(10^{4}\right.$ permutations). $P$ levels are indicated with asterisks (n.s., not significant).

\begin{tabular}{lcllcl}
\hline 2-way ANOSIM: PCR products & \multicolumn{2}{l}{ 2-way ANOSIM: RT-PCR products } \\
\hline Factor Age & & Factor Age & & \\
R: & 0.75 & & R: & 0.83 & \\
$P($ same): & 0.001 & $* *$ & $P($ same): & 0.0005 & $* * *$ \\
\hline Factor Diet & & & Factor Diet & & \\
R: & 0.23 & $*$ & R: & 0.08 & \\
$P($ same): & 0.04 & $*$ & $P($ same): & 0.30 & n.s. \\
\hline
\end{tabular}




\section{Table 8}

Identification of the OTUs marked in Fig. 4 , with similar nucleotide sequences found in GenBank (sequence identity in \%) and their approximate position on the gels (Rf value). Alteromonadaceae $\mathrm{S}$ and Oleispira sp. B were isolated at the same Rf, in the same way as Gilvimarinus sp. I and Pseudoalteromonas sp. J.

\begin{tabular}{|c|c|c|c|c|}
\hline Identification & Code (Fig. 4) & Similar GenBank ID & Identity (\%) & $\mathrm{Rf}$ \\
\hline \multicolumn{5}{|l|}{$\alpha$-Proteobacteria } \\
\hline$\alpha$-Proteobacterium & $\mathrm{R}$ & GU644361 & 83 & $0.814^{\S}$ \\
\hline Cohaesibacter sp. & $\mathrm{C}$ & DQ394095 & 98 & 0.638 \\
\hline Methylobacterium sp. D & $\mathrm{D}$ & GQ228559 & 99 & 0.952 \\
\hline Methylobacterium sp. E & $\mathrm{E}$ & $\mathrm{Z} 23160$ & 100 & 0.965 \\
\hline \multicolumn{5}{|l|}{$\gamma$-Proteobacteria } \\
\hline Alteromonadaceae & $\mathrm{S}$ & AF235108 & 97 & 0.700 \\
\hline Alteromonas sp. & $\mathrm{H}$ & AB712357 & 97 & 0.736 \\
\hline Colwellia sp. & M & FR744837 & 96 & 0.667 \\
\hline Enterobacteriaceae & $\mathrm{F}$ & JQ795141 & 99 & 0.855 \\
\hline Gilvimarinus sp. & I & FR750935 & 95 & 0.591 \\
\hline Leucothrix sp. & $\mathrm{T}$ & HQ897925 & 99 & 0.897 \\
\hline Oleispira sp. & B & EU980447 & 97 & 0.700 \\
\hline Pseudoalteromonas sp. & $\mathrm{J}$ & JQ178348 & 100 & 0.591 \\
\hline Thioalkalivibrio sp. & Q & NR_042862 & 96 & 0.802 \\
\hline Vibrio sp. A & A & JQ361736 & 99 & 0.781 \\
\hline Vibrio sp. G & G & FJ457610 & 99 & 0.787 \\
\hline Vibrio sp. O & $\mathrm{O}$ & JF412234 & 99 & 0.740 \\
\hline \multicolumn{5}{|l|}{$\delta$-Proteobacteria } \\
\hline Desulfotalea $\mathrm{sp}$. & $\mathrm{K}$ & NR_024949 & 97 & 0.605 \\
\hline \multicolumn{5}{|l|}{$\varepsilon$-Proteobacteria } \\
\hline Arcobacter sp. & $\mathrm{N}$ & AJ271654 & 99 & 0.357 \\
\hline Unidentified & $\mathrm{U}$ & - & - & 0.773 \\
\hline
\end{tabular}

${ }^{\S}$ Pediococcus acidilactici (P) had the same Rf (0.814) 


\section{Table 9}

Main OTUs responsible for BCP dissimilarity between diets at the two dates of sampling, and their contribution to the overall average dissimilarity (in brackets), according to SIMPER analysis.

\begin{tabular}{|c|c|c|c|c|}
\hline \multirow{2}{*}{$\begin{array}{l}\text { Age } \\
\text { Comparison }\end{array}$} & \multicolumn{2}{|c|}{$20 \mathrm{dph}$} & \multicolumn{2}{|c|}{$30 \mathrm{dph}$} \\
\hline & C vs. L & C vs. $\mathrm{P}$ & $\mathrm{L}$ & C vs. P \\
\hline \multicolumn{5}{|l|}{ Genomic DNA } \\
\hline Main dissimilar OTU & Vibrio sp. A & Vibr & Arcobacter sp. & $\begin{array}{c}\text { Alteromonas } \\
\text { sp. }\end{array}$ \\
\hline $\begin{array}{l}\text { Contribution (overall } \\
\text { dissimilarity) }\end{array}$ & $8.5(43.1)$ & $13.9(69.7)$ & $6.3(62.0)$ & $5.1(70.4)$ \\
\hline $\begin{array}{l}\text { cDNA } \\
\text { Main dissimilar OTU }\end{array}$ & Vibrio sp. G & Vibrio sp. G & $\operatorname{Rf} 0.835^{\S}$ & Rf 0.773 \\
\hline $\begin{array}{l}\text { Contribution (overall } \\
\text { dissimilarity) }\end{array}$ & $5.4(46.4)$ & $5.3(61.1)$ & $7.9(59.5)$ & $6.6(65.9)$ \\
\hline
\end{tabular}

${ }_{\S}^{\S}$ Lactobacillus casei X2 (L) and unidentified OTU had the same Rf (0.835) 


\section{Table 10}

Main OTUs responsible for BCP dissimilarity between the two dates of sampling, or between PCR and RT-PCR products, and their contribution to the overall average dissimilarity (in brackets), according to SIMPER analysis, with or without discriminating the diets

\begin{tabular}{|c|c|c|c|c|}
\hline Diet & $\mathrm{C}$ & $\mathrm{L}$ & $\mathrm{P}$ & All \\
\hline \multicolumn{5}{|c|}{ Comparison 20 vs. $30 \mathrm{dph}$} \\
\hline \multicolumn{5}{|l|}{ Genomic DNA } \\
\hline Main dissimilar OTU & Vibrio sp. A & Vibrio sp. A & Vibrio sp. G & Vibrio sp. A \\
\hline $\begin{array}{l}\text { Contribution (overall } \\
\text { dissimilarity) }\end{array}$ & $12.5(73.9)$ & $18.2(81.5)$ & $12.5(70.4)$ & $11.3(74.3)$ \\
\hline \multicolumn{5}{|l|}{ cDNA } \\
\hline Main dissimilar OTU & $\operatorname{Rf} 0.835^{\S}$ & $\operatorname{Rf} 0.835^{\S}$ & Vibrio sp. A & $\operatorname{Rf} 0.835^{\S}$ \\
\hline $\begin{array}{l}\text { Contribution (overall } \\
\text { dissimilarity) }\end{array}$ & $8.9(84.2)$ & $14.4(84.5)$ & $6.3(74.4)$ & $9.1(78.4)$ \\
\hline \multicolumn{5}{|c|}{$\begin{array}{l}\text { Comparison genomic vs. } \\
\text { cDNA }\end{array}$} \\
\hline \multicolumn{5}{|l|}{$20 \mathrm{dph}$} \\
\hline Main dissimilar OTU & $\mathrm{G}$ & Vibrio sp. G & Vibrio sp. G & Vibrio sp. A \\
\hline $\begin{array}{l}\text { Contribution (overall } \\
\text { dissimilarity) }\end{array}$ & & $9.4(56.7)$ & $6.9(61.5)$ & $7.9(65.8)$ \\
\hline \multicolumn{5}{|l|}{$30 \mathrm{dph}$} \\
\hline Main dissimilar OTU & $\operatorname{Rf} 0.835^{\S}$ & $\operatorname{Rf} 0.835^{\S}$ & Vibrio sp. $\mathrm{O}$ & $\operatorname{Rf} 0.835^{\S}$ \\
\hline $\begin{array}{l}\text { Contribution (overall } \\
\text { dissimilarity) }\end{array}$ & $8.9(88.2)$ & $14.4(82.8)$ & $5.4(66.7)$ & $9.2(69.8)$ \\
\hline
\end{tabular}

${ }^{\S}$ Lactobacillus casei X2 (L) and unidentified OTU had the same Rf (0.835) 
Figure 1A
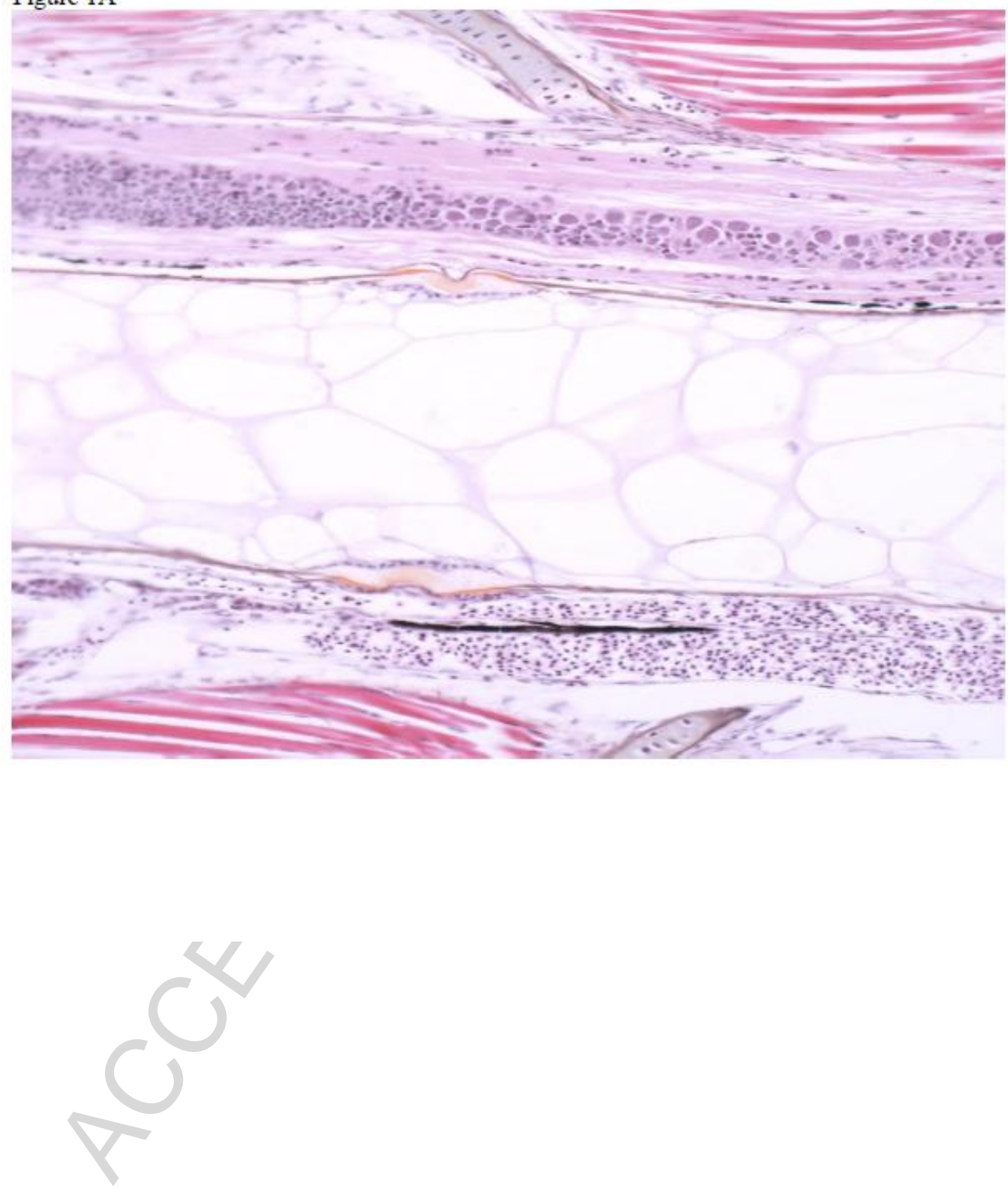


\section{ACCEPTED MANUSCRIPT}
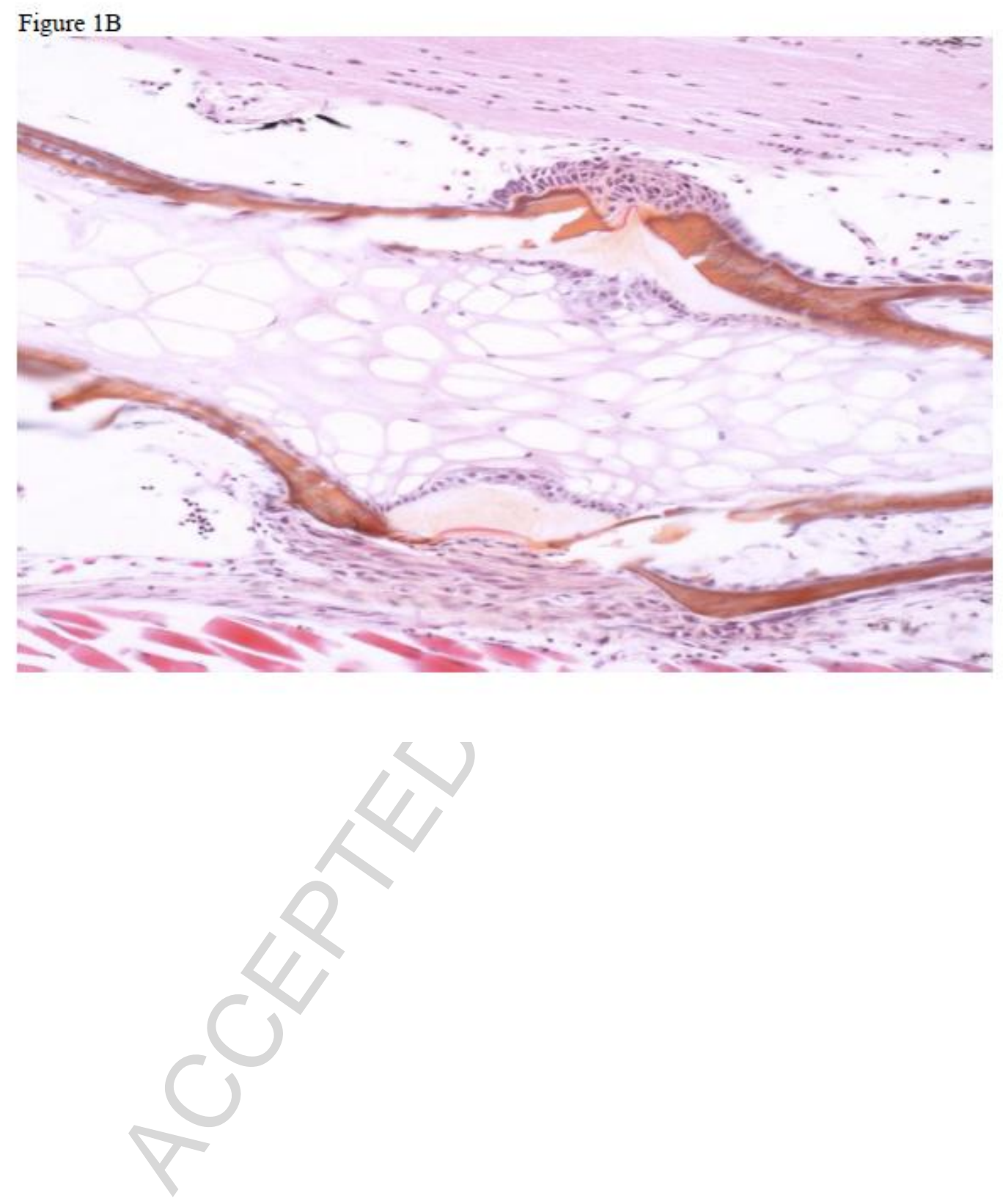
Figure 2A

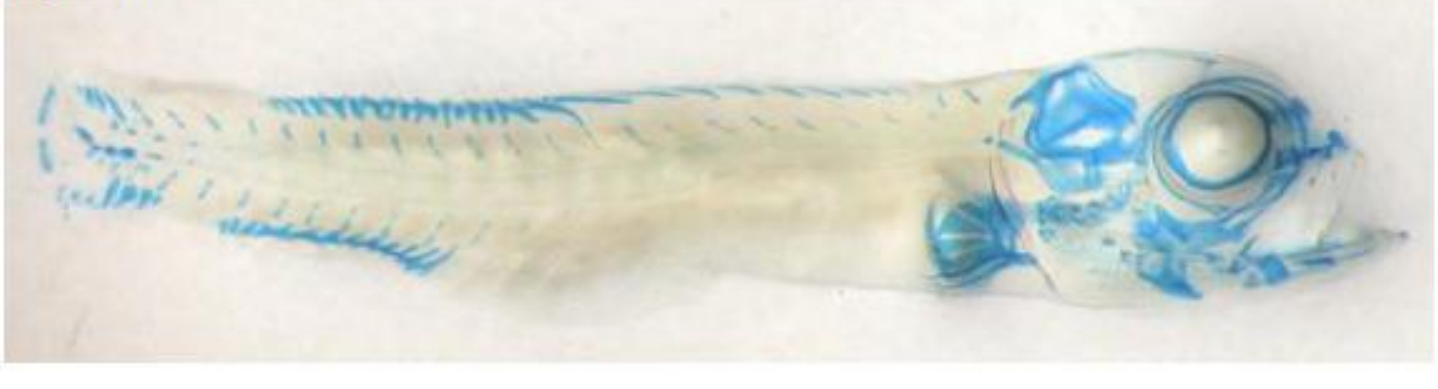

Figure 2B

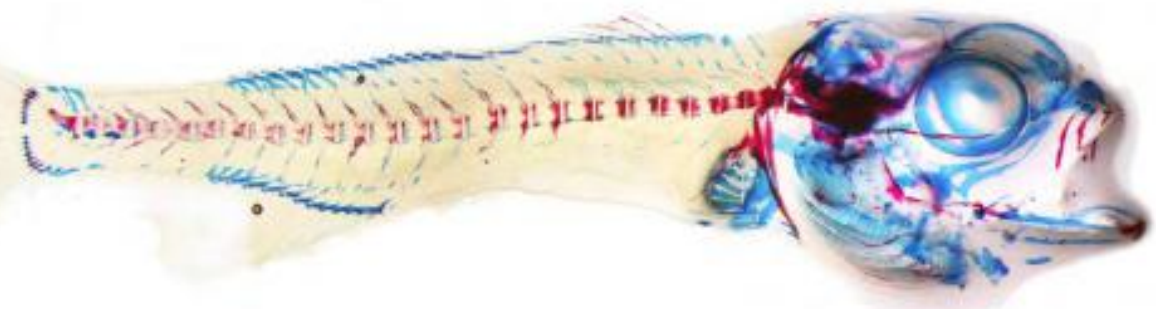

Figure 2C

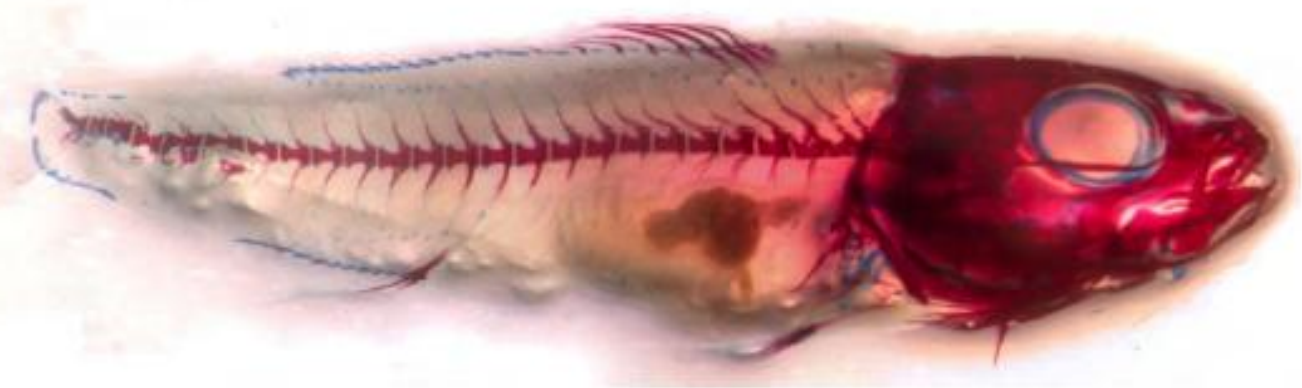




\section{ACCEPTED MANUSCRIPT}

Figure 3
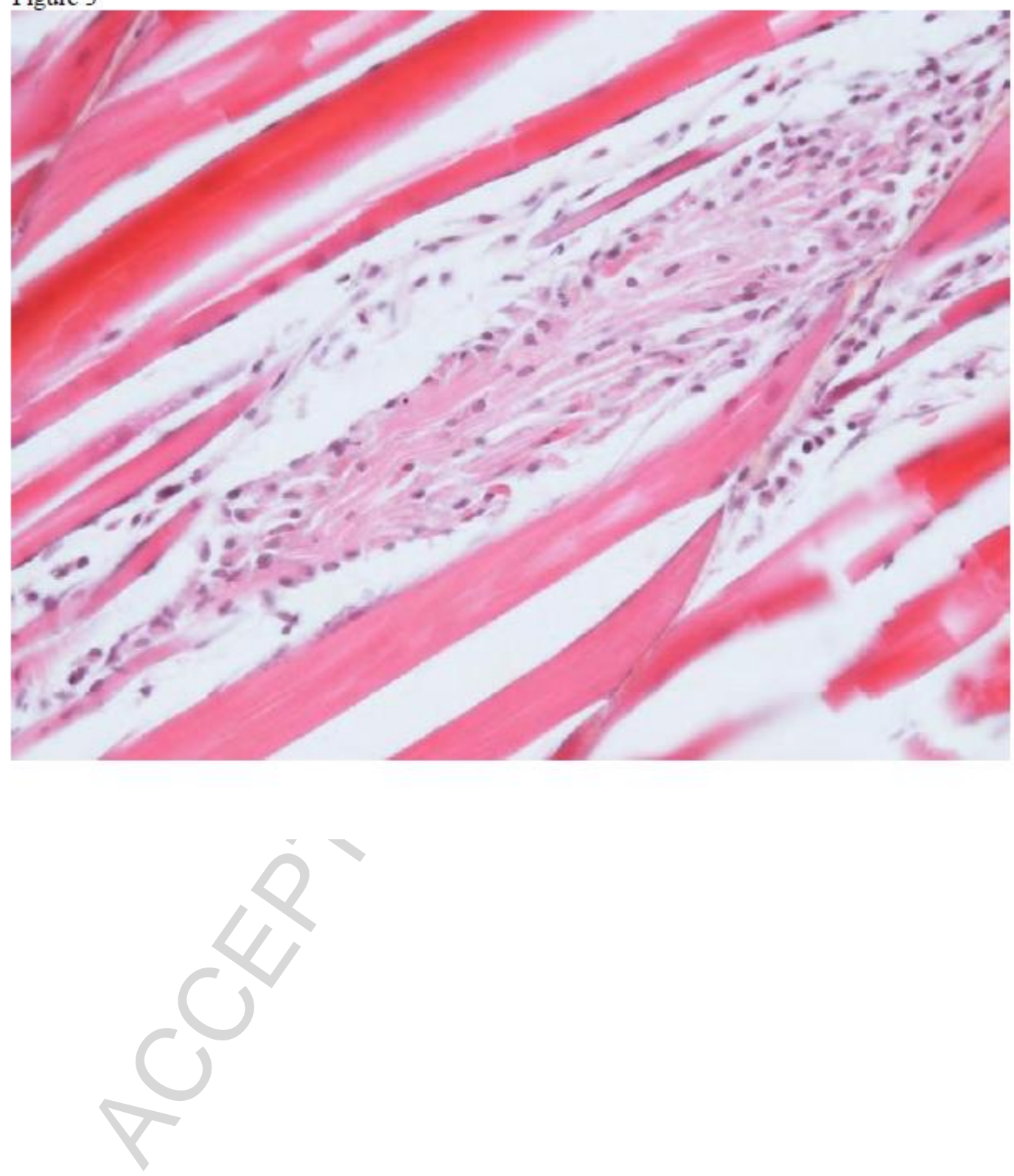
Figure 4
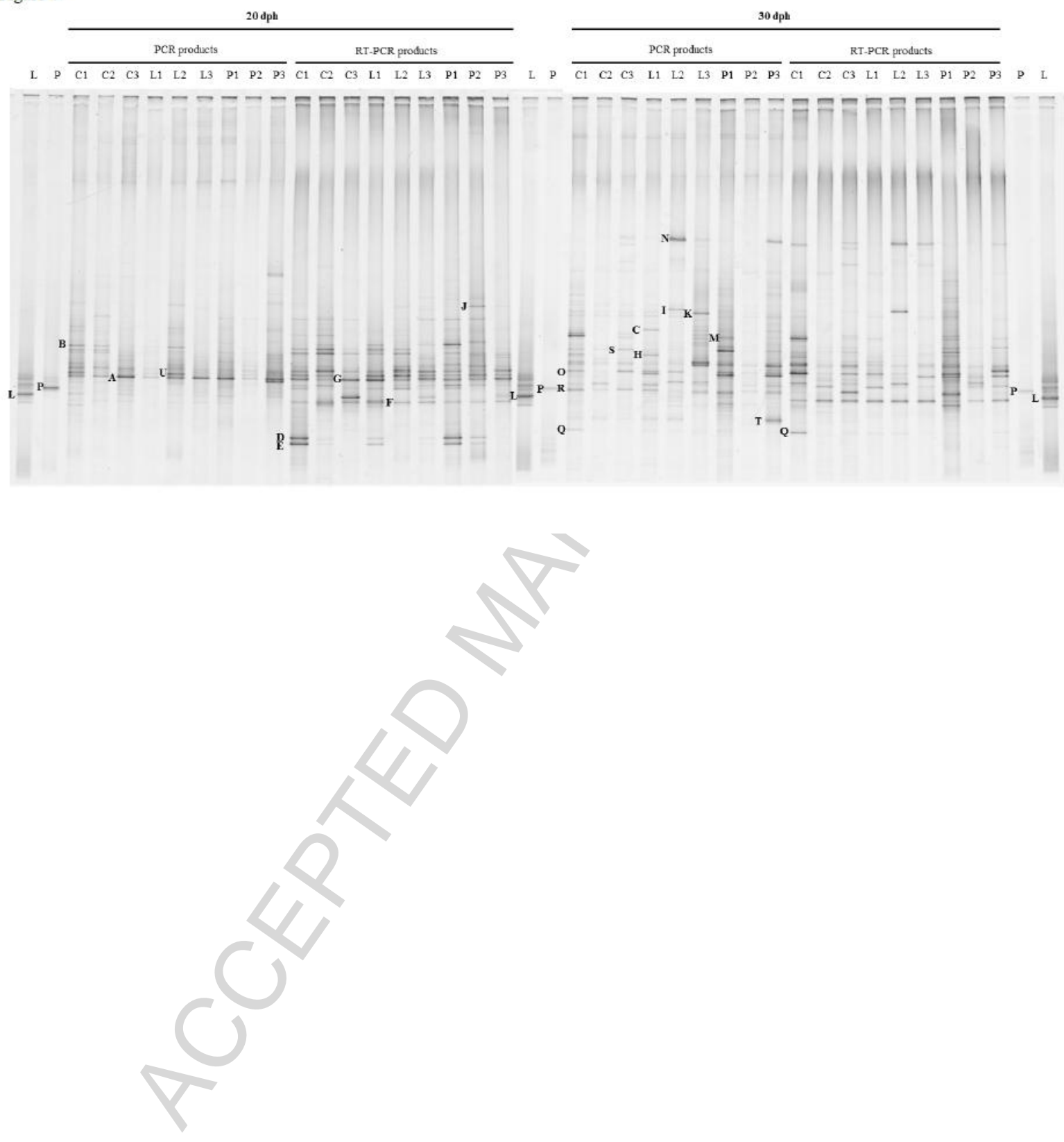
Figure 5

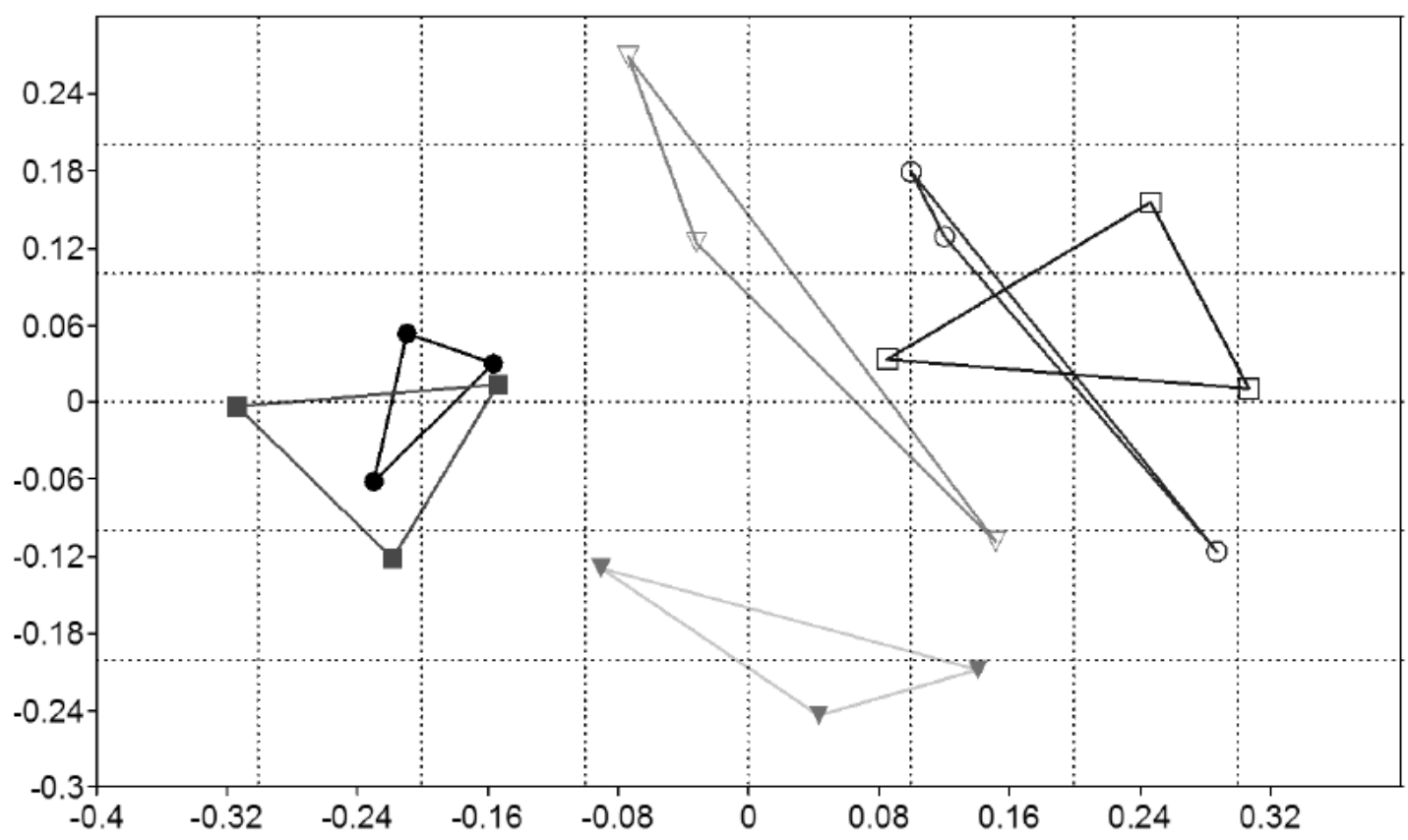


Figure 6
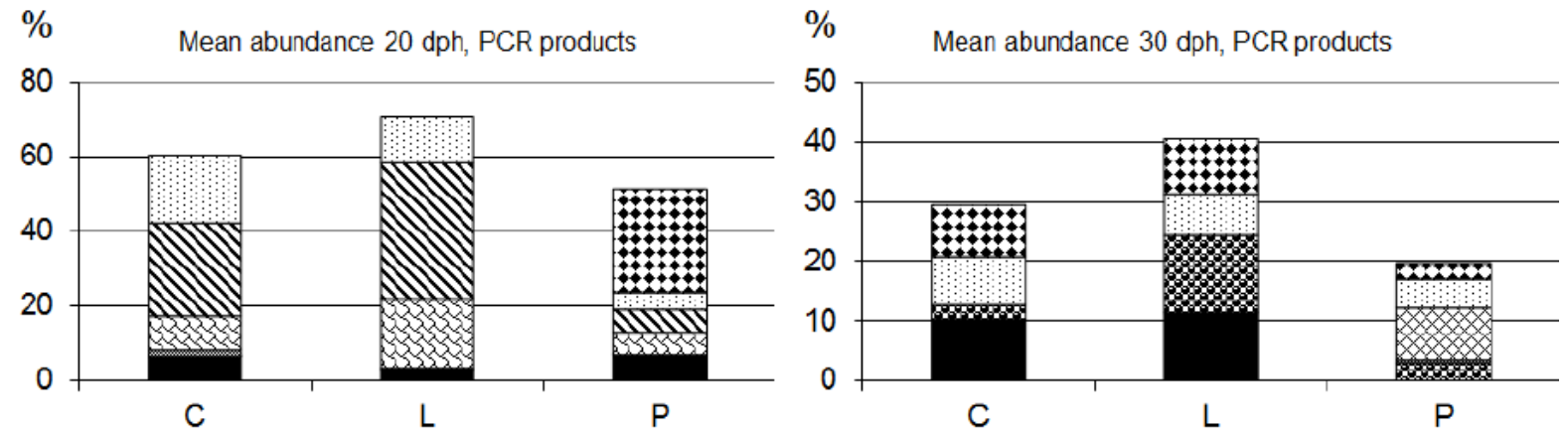

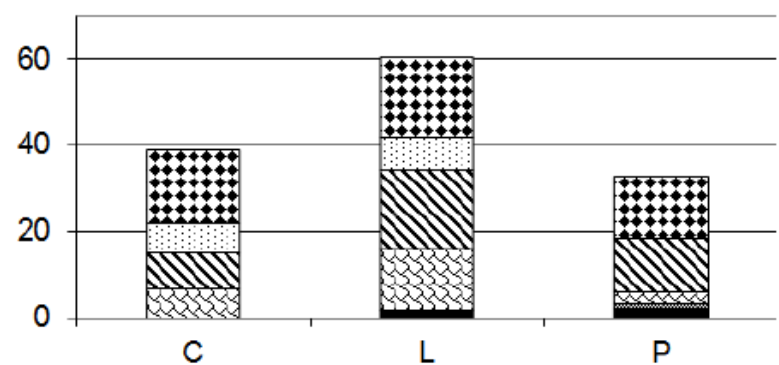

Mean abundance $20 \mathrm{dph}$ RT-PCR products

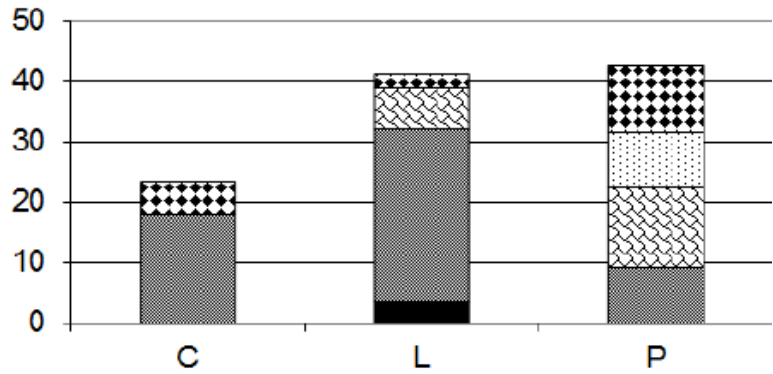

Mean abundance $30 \mathrm{dph}$, RT-PCR products

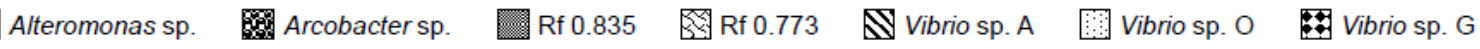

